\title{
PERBANDINGAN ANTARA MODEL PEMBELAJARAN EXAMPLE NON EXAMPLE DENGAN MODEL PEMBELAJARAN TALKING STICK TERHADAP PRESTASI BELAJAR PADA MATA PELAJARAN IPS EKONOMI MATERI POKOK PELAKU EKONOMI DALAM SISTEM PEREKONOMIAN INDONESIA PESERTA DIDIK KELAS VIII SMP NEGERI 1 ANGKOLA SELATAN TAHUN PELAJARAN 2016-2017
}

\author{
Muhaira(1), Rajab Ansari, M.Pd, E $^{(2)}$ \\ ${ }^{1}$ Mahasiswi Univeristas Muhammadiyah Tapanuli Selatan \\ ${ }^{2}$ Dosen FKIP Univeristas Muhammadiyah Tapanuli Selatan
}

\begin{abstract}
Abstrak
Rumusan masalah dalam penelitian ini adalah "Apakah ada perbandingan antara model pembelajaran example non example dengan model pembelajaran talking stick dengan prestasi belajar IPS Ekonomi Pada Materi pokok pelaku Ekonomi Dalam Sistem Perekonomian Indonesia peserta didik kelas VIII SMP Negeri 1 Angkola Selatan Tahun Pelajaran 2016-2017'? tujuan penelitian ini adalah :Untuk mengetahui prestasi belajar IPS Ekonomi menggunakan model pembelajaran example non example dan talking stick pada materi pokok pelaku ekonomi dalam sistem perekonomian Indonesia kelas VIII SMP Negeri 1 Angkola Selatan Tahun Pelajran 2016-2017. jenis penelitian yang digunakan adalah penelitian komparatif, yaitu penelitian yang bersifat membandingkan variabel yang satu dengan variabel yang lain terhadap objek yang berbeda. Ada perbandingan penggunaan model pembelajaran example non example dengan model pembelajaran talking stick Terhadap Prestasi Belajar IPS Ekonomi Pada Materi Pokok Pelaku Ekonomi Dalam Sistem Perekonomian Indonesia Tahun Pelajaran 2016-2017.
\end{abstract}

Kata Kunci: Model Pembelajaran, Pelaku Ekonomi, Pembelajaran Talking Stick

Pendahuluan

Model secara harfiah berarti "bentuk", dalam pemakaian secara umum model merupakan interpretasi terhadap hasil observasi dan pengukurannya yang diperoleh dari beberapa sistem. Model diartikan sebagai bentuk representasi akurat sebagai proses aktual yang memungkinkan seseorang atau sekelompok orang mencoba bertindak berdasarkan model itu.

Menurut S. Nasution bahwa : "Model adalah suatu cara yang digunakan untuk melaksanakan kegiata-kegiatan dalam 
suatu tugas atau pekerjaan agar menacapai tujuan sesuai dengan yang ditetapkan. Pembelajaran memiliki hakikat perencanaan atau perancangan (desain) sebagai upaya membelajarkan peserta didik. Itulah sebabnya dalam belajar, tetapi mungkin berinteraksi dengan keseluruhan sumber belajar yang dipakai untuk mencapai tujuan pembelajaran yang diinginkan. Menurut Ujang Sukandi adalah : "Pembelajaran memiliki suatu tema aktual, dekat dengan dunia peserta didik, dan kaitannya dengan kehidupan sehari-hari. Tema ini menjadi alat pemersatu materi yang beragam dari beberapa materi pelajaran. Menurut Kiranawati Example Non Example adalah "Model pembelajaran yang menggunakan contoh-contoh. Contoh-contoh dapat dari kasus/gambar yang relevan dengan kompetensi dasar. Example memberikan gambaran akan sesuatu yang menjadi contoh akan suatu materi yang sedang dibahas, sedangkan non example memberikan gambaran akan sesuatu yang bukanlah contoh dari suatu materi yang sedang dibahas. Example Non Example dianggap perlu dilakukan karena suatu definisi konsep adalah suatu konsep yang diketahui secara primer hanya dari segi definisinya dari pada dari sifat fisiknya. Jadi, example memberikan gambaran akan sesuatu yang menjadi contoh akan suatu materi yang sedang dibahas, sedangkan non-example memberikan gambaran akan sesuatu yang bukanlah contoh dari suatu materi yang sedang dibahas. Dengan memusatkan perhatian peserta didik terhadap example dan non example diharapkan akan dapat mendorong peserta didik untuk menuju pemahaman yang lebih dalam mengenai materi yang ada. Hary Kurniadi menyatakan bahwa"Model pembelajaran example non example atau juga biasa disebut example and non example merupakan model pembelajaran yang menggunakan gambar sebagai media pembelajaran. Penggunaan media gambar ini disusun dan dirancang agar anak dapat menganalisis gambar tersebut menjadi sebuah bentuk diskripsi singkat mengenai apa yang ada didalam gambar.

Tujuan pendidikan menurut lavebgeld yang dikutip Safri bahwa: "Pendidikan adalah bimbingan atau pertolongan yang diberikan oleh orang dewasa kepada perkembangan anak untuk mencapai kedewasaannya dengan tujuan agar anak cukup cakap dalam melaksanakan tugas hidupnya sendiri tanpa bantuan orang lain. Salah satu caranya adalah dengan mempelajari mata pelajaran IPS Ekonomi. Melalui mata pelajaran IPS Ekonomi peserta didik mampu mempersiapkan dirinya untuk dapat hidup di dalam lingkungan masyarakat luas. IPS Ekonomi adalah ilmu yang mempelajari perilaku manusia dalam memilih dan menciptakan kemakmuran.

Menurut hasil pengamatan yang dilakukan peneliti melalui observasi kelas dan wawancara dengan guru mata pelajaran IPS Ekonomi kelas VIII SMP Negeri 1 Angkola Selatan menunjukkan bahwa pencapaian prestasi belajar pada mata pelajaran IPS Ekonomi peserta didik kurang optimal. Asumsi dasar yang menyebabkan pencapaian prestasi belajar mata pelajaran IPS Ekonomi peserta didik kurang optimal adalah pemilihan model pembelajaran yang membuat peserta didik kurang semanagat dan kurangnya peran serta (keaktifan) 
peserta didik dalam Proses Belajar Mengajar (PBM). Karena metode yang digunakan guru dalam mengajar adalah metode ceramah dan peta konsep. Model pembelajaran example non example dan talking stick diharapkan dapat meningkatkan semangat belajar, pemahaman, dan mendorong peserta didik untuk berani mengemukakan pendapatnya. batasan masalah dalam penelitian adalah: perbandingan Antara model pembelajaran example non example dengan model pembelajaran talking stick terhadap prestasi belajar IPS Ekonomi Materi Pokok Pelaku Ekonomi Dalam Sistem Perekonomian Indonesia.

\section{Metode Penelitian}

Penelitian ini dilakukan di SMP Negeri 1 Angkola Selatan yang terletak di Jl. Simarpinggan, Kecamatan Angkola Selatan, Kabupaten Tapanuli Selatan. Penyusunan instrumen dilakukan berdasarkan ketiga variabel yaitu, Model Pembelajaran Example Non Example sebagai variabel $\left(\mathrm{X}_{1}\right)$, Model Pembelajran Talking Stick sebagai variabel $\left(\mathrm{X}_{2}\right)$ dan prestasi belajar peserta didik pada mata pelajaran IPS Ekonomi materi pokok Pelaku Ekonomi Dalam Sistem Perekonomian Indonesia sebagai variabel (Y). Teknik pengumpulan data yang penulis gunakan dalam penelitian ini adalah angket dan tes prestasi belajar Yang mana angket digunakan untuk membandingkan antara model pembelajaran example non example dengan model pembelajaran talking stick, dan tes prestasi belajar digunakan untuk mengetahui ptrestasi belajar peserta didik pada mata pelajaran IPS Ekonomi materi pokok Pelaku
Ekonomi Dalam Sistem Perekonomian Indonesia.

Data-data yang sudah terkumpul kemudian akan dilakukan analisa lebih lanjut, untuk menguji hipotesis yang ditetapkan dalam penelitian ini. Adapun rumus yang dipergunakan untuk menguji hipotesis dimaksut adalah rumus "t-test polled varians, yaitu:

$$
t=\frac{\bar{X}_{1}-\bar{X}_{2}}{\sqrt{\frac{\left(n_{1}-1\right) S_{1}^{2}+\left(n_{2}-1\right) S_{2}^{2}}{n_{1}+n_{2}-2}\left(\frac{1}{n_{1}}+\frac{1}{n_{2}}\right)}}
$$

untuk mengetahui data tersebut nyata atau tidak peneliti mengukur kualitas dan menggunakan tabel penolong dengan ketentuan. Jika $\mathrm{t}$ hutung $>\mathrm{t}$ tabel maka koefisien korelasi yang di uji diterima, sebaliknya jika $\mathrm{t}$ hitung $<\mathrm{t}$ tabel maka koefisien korelasinya yang di uji adalah ditolak.

\section{Pembahsan Dan Hasil}

Dalam penelitian ini peneliti membahas suatu permasalahan yaitu: “ apakah ada perbandingan prestasi belajar mata pelajaran IPS Ekonomi melalui model pembelajaran example non example dan model pembelajaran talking stick materi pokok pelaku ekonomi dalam sistem perekonomian indonesia peserta didik di kelas VIII SMP Negeri 1 Angkola Selatan tahun pelajaran 2016-2017".

Setelah dilakukan pengujian hipotesis dengan rumus t-test polled varians diperoleh hasil $t_{\text {hitung }}=3.4$ sedangkan nilai $\mathrm{t}_{\text {tabel }}=2,021$, ini menunjukkan $\mathrm{t}_{\text {hitung }}>\mathrm{t}_{\text {tabel }}$ atau $(3,4>2,021)$ artinya ada perbandingan prestasi belajar mata pelajaran IPS Ekonomi melalui model pembelajaran example non 
example dan model pembelajaran talking stick materi pokok Pelaku Ekonomi Dalam Sistem Perekonomian Indonesia peserta didik di kelas VIII SMP Negeri 1 Angkola Selatan tahun pelajaran 2016-2017.

\section{Kesimpulan}

Penulis menyimpulkan dan memberikan saran. Adapun yang menjadi kesimpulan sebagai berikut :

1. Penggunaan model pembelajaran example non example dan model pembelajaran talking stick terhadap prestasi belajar mata pelajaran IPS Ekonomi pada materi pokok Pelaku Ekonomi Dalam Sistem Perekonomian Indonesia peserta didik di kelas VIII SMP Negeri 1 Angkola Selatan Tahun Pelajaran 2016-2017 di kategorikan Baik

2. Data yang diperoleh dengan tekhnik analisa data dengan menggunakan rumus t-tes polled varians. Setelah dilakukan analisa data maka thitung adalah 3,4 dengan melihat daftar

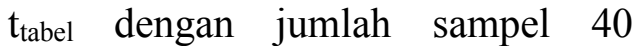
dengan derajat kebebasan $(\mathrm{dk})=\mathrm{n}_{1}$ $+n_{2}-2$ dan taraf kesalahan 5\% adalah 2,021 dengan demikian dapat diketahui $t_{\text {hitung }}$ lebih besar dari tabel yaitu 3,4 > 2,021 maka hipotesis alternative $(\mathrm{Ha})$ dapat diterima.

3. Ada perbandingan penggunaan model pembelajaran example non example dengan model pembelajaran talking stick Terhadap Prestasi Belajar IPS Ekonomi Pada Materi pokok Pelaku Ekonomi Dalam
Sistem Perekonomian Indonesia Tahun Pelajaran 2016-2017.

\section{Saran}

1. Kepada para peserta didik diharapkan untuk lebih giat lagi belajar IPS Ekonomi dalam meningkatkan prestasi belajar yang lebih baik untuk masa yang akan datang.

2. Kepada guru hendaknya lebih meningkatkan kemampuannya dalam mengajar dengan memilih model pembelajaran yang dapat menunjang prestasi belajar IPS Ekonomi peserta didik.

3. Kepada kepala sekolah selaku pembina dalam organisasi sekolah, agar selalu memperhatikan, membimbing dan mengarahkan para guru dan peserta didik dalam memberikan pendidikan kearah yang lebih baik.

4. Kepada rekan-rekan mahasiswa dan para peneliti yang ingin memperdalam penelitian tentang penggunaan model pembelajaran untuk meningkatkan prestasi belajar dianjurkan untuk melihat dari sisi lain, sehingga hasil belajar IPS Ekonomi peserta didik pada materi pokok Pelaku Ekonomi Dalam Sistem Perekonomian Indonesia akan semakin meningkat.

\section{Daftar Pustaka}

Arikunto Suharsimi, 2009. Manajemen Penelitian, Jakarta : PT Rineka Cifta 
Agus Supriyono, 2009. Cooperative Learning: Teori dan Aplikasi Paikem. Yogyakarta: Pustaka Belajar.

B. Uno Hamzah, Mohammad Nurdin, 2012. Belajar Dengan Pendekatan Pailkem, Jakarta: Bumi Aksara Daryanto, 2010. Evaluasi Pendidikan,Jakarta: Rineka Cipta

David Indrianto danApriani, Atik, 2010. Implementasi Model Pembelajaran Example Non Example. Sumedang:FKIP PGMI. IKIP PGRI

Gagne,2012Proses Belajar Mengajar Di Sekolah, Jakarta:Rineka Cipta

Huda Miftahul, 2014. Model-Model Pengajaran Dan Pembelajaran, Yogyakarta: Pustaka Pelajar

Istarani, 2011. Model Pembelajaran Inovatif. Sidoarjo: Masmedia Buana Pustaka

Kunandar, 2007. Guru Profesional/Implementasi Kurikulum Tingkat Satuan Kompetensi (KTSP) Dan Sukses Dalam Sertifikasi Guru, Jakarta: Raja Grafindo Persada

Kurniadi Hary, 2010. Model Pembelajaran Examples Non Examples, Jakarta : RinekaCipta

Mulyasa,2015.Ensiklopedi

Pendidikan,Medan,MediaPersada

Nasution. S, 2007. Pengembangan Kurikulum,Bandung : Alumni

Nurbako Cholid, 2007. Metode Penelitian Pendidikan Pendekatan Kuantitatif, Kulaitatif dan $R \& D$. Jakarta: Rineka Cipta
Ruhimat Mamat, 2006. IPS Untuk Kelas VII, Bandung Grafindo Media Pratama

Safri, 2012. Pengantar Pendidikan,Padang : Sukabina Press

Sagala Syaiful, 2008. Konsep Dan Makna Pembelajaran, Untuk Membantu Memecahkan Problematika Belajar Dan Mengajar, Bandung: Alfabeta

Sardiman, 2003. Interaksi dan Motivasi Belajar Mengajar, Jakarta : Raja Grafindo Persada

Sudjana Nana, 2010. Penelitian Tindakan Kelas Sebagai Pengembang Tindakan Guru, Jakarta:Rajawali Pers

Sugiyono, 2004. Statistika Untuk Penelitian, Bandung : CV Alfabeta

Sukandi Ujang, 2007. Model Pembelajaran Terpadu, Jakarta : Prestasi Pustaka

Suyatno, 2009. Menjelajah Pembelajaran Inovatif, Sidoarjo: Masmedia Buana Pustaka 